\title{
BERMAIN DAN BERINTERAKSI DENGAN AMERICAN NATIVES SEBAGAI METODE BELAJAR ANAK DI KEDIRI, JAWA TIMUR
}

\author{
Ika Silviana ${ }^{1}$, Fatma Puri Sayekti ${ }^{2}$ \\ ${ }^{1}$ Program Studi Sosiologi Agama, Jurusan Ushuluddin dan Ilmu Sosial IAIN Kediri \\ ${ }^{2}$ Program Studi Psikologi Islam, Jurusan Ushuluddin dan Ilmu Sosial IAIN Kediri \\ e-mail: ${ }^{1}$ veana_ieka@yahoo.com, ${ }^{2}$ fatmapuri@gmail.com
}

\begin{abstract}
Reading parks or public library generally offer the focal point of literacy activities with the encouragement of people reading interest. These activities undertaken by providing a reading room and socializing the importance of reading. This social service along with Taman Baca Puri Anjali, located in Kaliombo, Kediri, East Java, observes the problems related to learning methods, especially in reading, that occur in children. Through the activity titled "Kids, Are You Ready to Talk to American Native?" together create learning activities by playing, based on Paulo Freire's method, conscientizacao. This activity invites children to learn English directly with people who use English language in their daily life, named American natives. It has a happy learning effect on children and they feel that learning English is easier than before. They also assimilate a more varied pattern of literacy, without leaving the books that become the world's window for learners.
\end{abstract}

Keywords - Public Library, Conscientizacao, and American Native

\begin{abstract}
Abstrak
Taman baca pada umumnya lebih memilih titik fokus kegiatan berliterasi dengan penggalakkan minat baca masyarakat. Kegiatan yang dilakukan dengan memberikan ruang baca serta mensosialisasikan pentingnya membaca. Pengabdian ini bersama dengan Taman Baca Puri Anjali, sebagai salah satu taman baca di Kediri, Jawa Timur, menilik adanya permasalahan terkait metode belajar (membaca) yang terjadi pada anak-anak. Melalui kegitan "Kids, Are You Ready to Talk to American Native" bersama-sama menciptakan kegiatan belajar dengan metode bermain, dengan mendasarkan pada metode conscientizacao besutan Paulo Freire. Kegiatan ini mengajak anak-anak belajar berbahasa Inggris secara langsung bersama orang-orang yang menggunakan bahasa inggris dalam kesehariannya, yaitu American natives. Kegiatan ini memberikan efek bahagia belajar pada anak-anak dan mereka merasa belajar berbahasa inggris itu mudah. Anak-anak juga meraskan pola berliterasi yang lebih bervariatif, tanpa harus meninggalkan buku-buku yang menjadi jendela dunia bagi para pembelajar.
\end{abstract}

Kata Kunci-Taman Baca, Conscientizacao, Dan American Native

\section{PENDAHULUAN}

Permasalahan literasi, khususnya kedekatan anak-anak dengan buku menjadi titik fokus yang menarik dari berbagai kalangan. Fokus ini menjadi perhatian masyarakat di banyak wilayah di Indonesia, termasuk di Kota Kediri. Banyak penelitian sebelumnya yang berupaya untuk membangun semangat baca bagi anak-anak sebagai upaya pemangkasan buta huruf di Indonesia. Sesuai data PIRLS yang disampaikan oleh Hardhini Permatasari, bahwa realitas ini sebagai akibat dari sempitnya pengenalan anak-anak atas perpustakaan yang hanya terfokus pada perpustakaan sekolah, tidak adanya integrasi anatara mata pelajaran di sekolah dengan kewajiban siswa membaca, serta proses pengenalan pra-membaca dan membaca yang buruk sehingga minat baca anak rendah [1]. Maka, upaya yang sudah banyak dilakukan adalah dengan memberikan fasilitas perpustakaan hingga ke lini desa, serta memberikan sosialisasi pada masyarakat akan pentingnya kegiatan membaca. Namun, dari kegiatan-kegiatan yang sudah dilakukan, ditemukan celah bahwa 
kegiatan beliterasi perlu adanya penyegaran dari sisi metode belajarnya. Perlu cara belajar yang menarik yang disesuaikan dengan kebutuhan anak-anak di zaman ini.

Dewasa ini, perlu adanya pemaknaan kembali atas adagium 'buku adalah jendela dunia'. Bukan karena sudah tidak relevan bagi para pembelajar zaman ini, melainkan perkembangan IPTEK membutuhkan respon strategis dalam memupuk semangat belajar anak-anak. Mengingat generasi milenial yang sangat dekat dengan teknologi, kini anak-anak telah menemukan jendela dunia baru melalui gawai. Pekerjaan rumah bagi orang dewasa yang memiliki kewajiban menularkan budaya belajar, tanpa meninggalkan belajar melalui setuahan buku-buku. Langkah yang perlu dipilih adalah langkah inovatif dengan tidak memaksakan anak belajar melalui metodemetode konservatif. Menilik semakin beratnya beban belajar anak-anak di sekolah formal, maka perlu adanya kegiatan belajar dengan metode bermain, yakni sebagai pengganti waktu bermain anak-anak yang telah direnggut oleh sistem kurikulum baru-baru ini.

Taman Baca Puri Anjali yang beralamatkan di Jl. Mangga no. 74 Kaliombo Kediri, Jawa Timur ingin mengambil peran dalam upaya pembebasan anak-anak dari jerat pendidikan yang kian ketat. Melalui kegiatan-kegitan yang inovatif, Taman Baca Puri Anjali berlahan menemukan metode belajar yang menyenangkan bagi anak-anak. Tidak hanya mengenalkan literasi pada anakanak dengan gerakan membaca, tetapi juga melakukan aktivitas literasi yang lebih variatif. Meliputi kegitan membaca, menulis, berbicara, proses kreatif dalam pikiran, dan menghasikan karya. Pola berliterasi ini tidak lepas dari penggunaan buku sebagai landasan berkegiatan, hanya saja proses belajarannya menggunakan metode yang juga memupuk kebahagiaan anak-anak.

Pada kesempatan yang bertepatan dengan adanya dua orang relawan dari Amerika (American natives) yang sedang bertugas mengajar di Jawa Timur, bersama Taman Baca Puri Anjali mengundang para relawan ini untuk berbagi ilmu dengan anak-anak di Kediri. Berkomunikasi dengan orang-orang dari negara barat merupakan salah satu bentuk praktik berliterasi yang dapat dilakukan anak-anak, sebagai ejawantah dari pembelajaran buku-buku berbahasa Inggris. Sebagaimana kita ketahui, sejak usia dini pun anak secara langsung maupun tidak langsung sudah kenal dengan bahasa Inggris, baik melalui lagu, permainan, atau tontonan video di televisi maupun gawai yang diberikan orangtuanya. Anak TK dan SD di beberapa sekolah juga sudah mendapatkan pelajaran Bahasa Inggris setiap minggunya.

Selain itu, acara ini juga memberikan pengalaman berharga bagi anak-anak untuk berbagi cerita dengan orang baru dan berasal dari negara lain. Anak-anak diharapkan akan mempunyai rasa percaya diri untuk berkomunikasi dengan siapapun, termasuk dengan orang-orang berkulit putih. Mereka dapat melihat sendiri bagaimana orang yang memiliki ras, agama dan budaya yang berbeda dengan yang mereka temui selama ini. Pemahaman atas identitas budaya lain merupakan kunci keberhasilan komunikasi antar budaya, karena tidak menutup kemungkinan bahwa ketidakpahaman atas budaya lain berpotensi terciptanya konflik antar budaya [2]. Hal ini dianggap penting, mengingat negara Indonesia merupakan salah satu negara jajahan dari negara orang-orang berkulit putih. Pengenalan sedari dini diharapkan dapat mengurangi mental inlander yang secara tidak sadar dibangun oleh sejarah. Toleransi pun ditumbuhkan sejak kecil untuk dapat menerima perbedaan yang ada.

\section{METODE}

Proses belajar yang dihadapi anak-anak di Taman Baca Puri Anjali ini adalah salah satu bentuk proses pendidikan. Porsi pendidikan yang diaplikasikan adalah pola pendidikan consciaentizacao besutan Paulo Freire. Tujuan pendidikan yang memberikan kebebasan pada peserta didik menjadi arah dari gerakan ini. Metode ini merupakan metode belajar yang tidak hanya melakukan transfer informasi pada peserta didik, melainkan adanya proses dialogis antara individu-individu dalam proses belajar untuk memecahkan permasalahan secara bersama-sama, dengan penciptaan pembebasan melalui norma, aturan, dan kebijakan baru. [3]. Consciaentizacao melihat pendidikan bukan sebagai pengorganisasian fakta yang sudah jadi, sehingga tinggal menyodorkan pada orang bodoh yang akan dianggapnya sebagai pengetahuan baru. Tetapi, pernyataan-pernyataan yang diajukan dalam proses belajar tidak memiliki jawaban sebelumnya, dan perlu adanya proses pencarian jawaban secara komprehensif atas masalah yang harus dihadapi oleh suatu kelompok belajar. 
Mendasarkan pada metode belajar tersebut, perlu adanya aturan pembelajaran baru yang harus dipraktikkan bersama-sama dengan anak-anak dan melibatkan mereka secara langsung untuk membangun pengetahuan secara bebas. Kegiatan yang diusung oleh Taman Baca Puri Anjali dengan judul "Kids, Are You Ready to Talk to American Native?" mengajak anak-anak untuk belajar bahasa Inggris melalu praktik langsung bersama relawan Amerika yang diundang. Metode yang digunakan dalam kegiatan ini adalah metode permainan, meliputi:

1. Melakukan gerak tubuh, untuk merangsang motorik anak dengan kegiatan senam bersama dan bernyanyi.

2. Pos 1 Introducing your selves: perkenalan nama, alamat rumah, kelas, dan sekolah.

3. Pos 2 Mentioning things around you: mengenal benda-benda di sekitar rumah (daun, batang, bunga, buah, tembok, tanah, semut, dan lain-lain. Benda yang ditemui di sekitar pos).

4. Pos 3 Reading books: membaca buku cerita bergambar berbahasa Inggris yang menarik bagi anak-anak, bertujuan untuk menambah kosa kata baru yang belum dipahami.

5. Pos 4 What was in books?: mengulang kembali materi dengan mengingat benda dan atau hewan yang ada didalam buku yang telah dibaca di pos 3 dan menceritakan kembali isi buku.

Panduan belajar di atas disusun untuk memudahkan anak-anak dalam mengoordinasikan pengetahuan mereka. Mulai dari proses berkenalan dengan teman baru, mengidentifikasi benda di sekitar, mencari, mengingat, dan kemudian menceritakan kembali sesuai dengan pengetahuan dan pemahaman yang terbentuk selama proses belajar. Susunan acara secara rinci adalah sebagai berikut:

\begin{tabular}{|c|c|}
\hline \multicolumn{2}{|r|}{ SUSUNAN KEGIATAN } \\
\hline Waktu & Kegiatan \\
\hline $07.00-07.30$ & Panitia briefing \\
\hline $\mathbf{0 7 . 3 0}-\mathbf{0 8 . 0 0}$ & Registrasi peserta dan pembagian kertas tanda nama \\
\hline $08.00-08.30$ & $\begin{array}{l}\text { Pengkondisian awal: senam, bernyanyi, perkenalan dengan } \\
\text { American natives, pembentukan kelompok }\end{array}$ \\
\hline \multirow[t]{2}{*}{$08.30-09.15$} & $\begin{array}{l}\text { Kelompok 1: bercerita bareng American natives di dalam ruangan } \\
\text { (dibagi menjadi } 2 \text { kelompok kecil) }\end{array}$ \\
\hline & $\begin{array}{l}\text { Kelompok 2: menjelajah kebun dengan } 4 \text { pos pemberhentian } \\
\text { (dibagi menjadi } 4 \text { kelompok kecil) }\end{array}$ \\
\hline \multirow[t]{2}{*}{$09.15-10.00$} & $\begin{array}{l}\text { Kelompok 2: bercerita bareng American natives di dalam ruangan } \\
\text { (dibagi menjadi } 2 \text { kelompok kecil) }\end{array}$ \\
\hline & $\begin{array}{l}\text { Kelompok 1: menjelajah kebun dengan } 4 \text { pos pemberhentian } \\
\text { (dibagi menjadi } 4 \text { kelompok kecil) }\end{array}$ \\
\hline $10.00-11.00$ & $\begin{array}{l}\text { Refleksi kegiatan: mengulang kembali materi, tanya jawab, pesan } \\
\text { dan kesan dengan American natives, penutup, foto bersama, anak- } \\
\text { anak pulang. }\end{array}$ \\
\hline $11.00-12.00$ & $\begin{array}{l}\text { Seluruh panitia makan siang dan "ngobrol santai" dengan } \\
\text { American natives serta foto bersama. }\end{array}$ \\
\hline
\end{tabular}

\section{HASIL DAN PEMBAHASAN}

Pelaksanaan kegiatan "Kids, Are You Ready to Talk to American Native?" tidak luput dari kerjasama dengan berbagai pihak. Relawan Taman Baca Puri Anjali bersama dengan relawan Gerakan Perpustakaan Anak Nusantara (GPAN) Kediri dan para tutor program English Massive daerah Kelurahan Kaliombo, Kelurahan Kampung Dalem dan Dukuh Corekan mulai membentuk kepanitiaan dan menyusun konsep serta rundown acara sebulan sebelum acara berlangsung. English Massive sendiri adalah sebuah program dari Pemerintah Kota Kediri yang menyediakan pembelajaran Bahasa Inggris gratis bagi warga, dengan menggunakan tempat yang disediakan oleh masing-masing desa dan kelurahan di seluruh Kota Kediri.

Kuota awal acara ini hanya 40 orang saja, dengan memertimbangkan luas lokasi dan jumlah sumber daya manusia yang ada. Namun, pemanfaatan media sebagai sarana publikasi, yakni 
membuat poster kegiatan yang dibagikan pada anak-anak yang aktif pada kegiatan English Massive, serta publikasi digital melalui media sosial Instagram dan Facebook, menunjukkan respon yang jauh lebih banyak dari perkiraan. Terdapat 102 anak yang menjadi peserta.

Anak-anak yang hadir pada kegiatan ini berangkat dari berbagai latar belakang dan usia. Anak dari keluarga yang mampu, kurang mampu, tinggal di rumah sendiri, di pondok pesantren, diantar kedua orangtuanya, diantar salah satu orangtua, maupun berangkat sendiri, semua berbaur menjadi satu. Ada yang berangkat menggunakan mobil, motor, sepeda, bahkan berjalan kaki karena lokasi yang tidak terlalu jauh dari rumah mereka.

Usia mereka juga variatif, mulai dari usia prasekolah, TK hingga SD. Pada kegiatan ini tidak melakukan tipologi atas anak-anak tersebut. Mereka memiliki kesempatan belajar bersama-sama sesuai dengan kemampuan belajar masing-masing. Diaharapkan, dari perbedaan latar belakang tersebut mereka menemukan pengalaman dan pemahaman baru atas proses belajar dan membangun relasi sosial yang setara antar teman yang mereka temui.

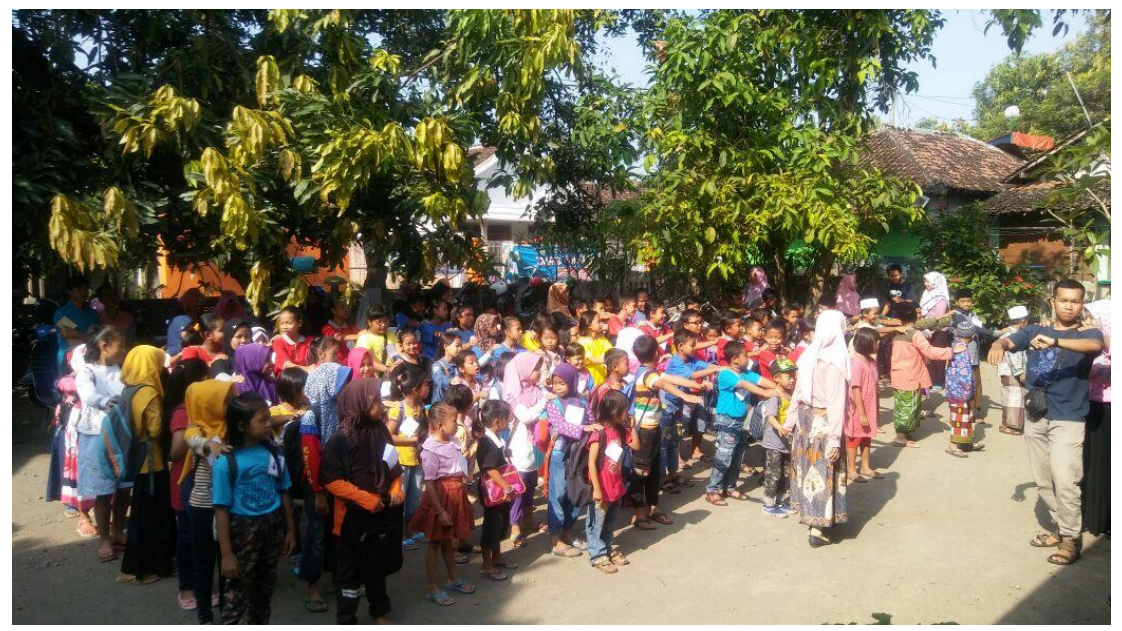

Gambar 1. Kegiatan senam dan bernyanyi bersama

Sebelum kegiatan dilakukan, anak-anak diajak berkumpul di halaman, dengan membuat barisan untuk senam bersama, sambil bernyanyi. Bertujuan untuk melemaskan otot, memberikan efek relaksasi, dan membuat bahagia. Kondisi tubuh yang segar dan perasaan yang bahagia membantu anak mampu belajar secara efektif. Ini menjadi salah satu strategi menuju kebebasan belajar. Tidak hanya memfokuskan pada kegiatan secara kognitif, tetapi memenuhi hak tubuh terlebih dahulu untuk merasa nyaman dengan lingkungan dan cara belajar. Kemudian baru melakukan transformasi pengetahuan melalui media-media yang digunakan.

Kegiatan selajutnya anak-anak dibagi menjadi dua kelompok yang masing-masing kelompok akan bertemu dan berkenalan secara langsung dengan American natives dan melakukan kegiatan jelajah kebun yang dibagi dalam 4 pos. Di masing-masing pos, mereka diberikan tantangan untuk saling mengenal teman dalam satu kelompok dan bekerja sama dalam menyelesaikan kegiatan.
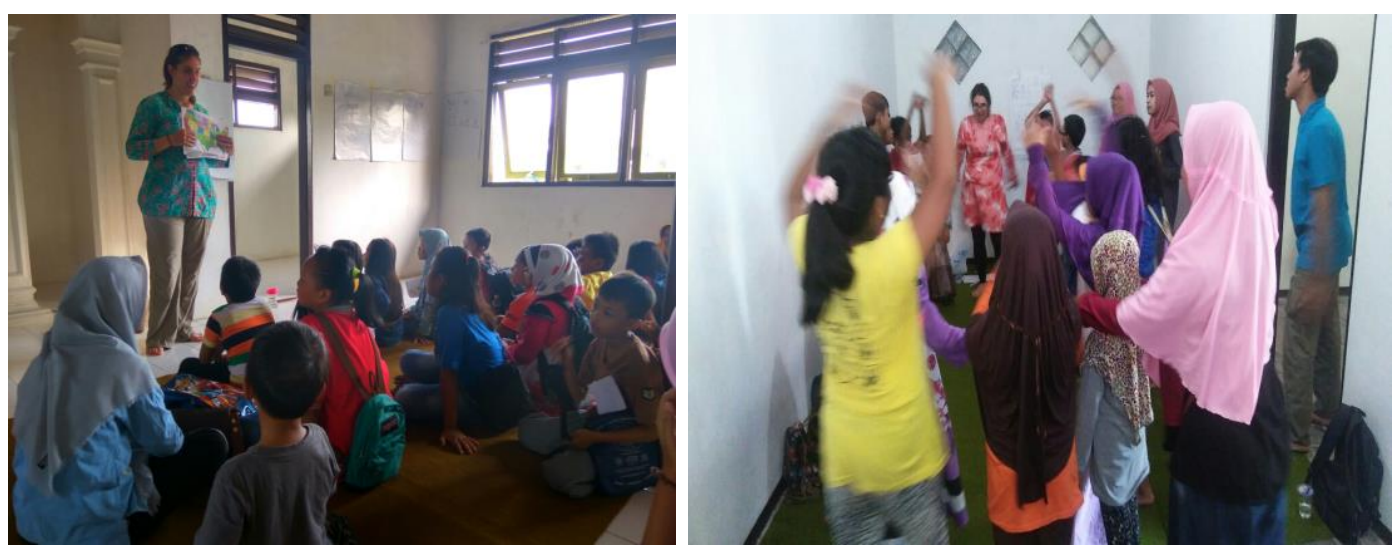

Gambar 2. Anak-anak berinteraksi langsung dengan American natives 
Berinteraksi langsung dengan Miss Sapphire Carter dari Montana dan Miss Kiara Jane dari California, Amerika Serikat, merupakan pengalaman baru bagi anak-anak. Mereka berkesempatan mempraktikkan kosa kata yang mereka pelajari dalam buku berbahasa Inggris untuk digunakan berkomunikasi dengan American natives. Pada kesempatan ini, mereka berbagi pengalaman terkait negara Amerika, meliputi makanan khas, macam-macam musim, baju daerah, kebiasaan yang dilakukan oleh orang-orang Amerika, menggunakan istilah-istilah keseharian, dan membangun kedekatan dengan melakukan permainan tebak kata serta mengenal anatomi tubuh manusia menggunakan bahasa Inggris. Miss Sapphire dan Miss Kiara juga mengajari lagu anak-anak berbahasa Inggris yang mudah ditirukan.
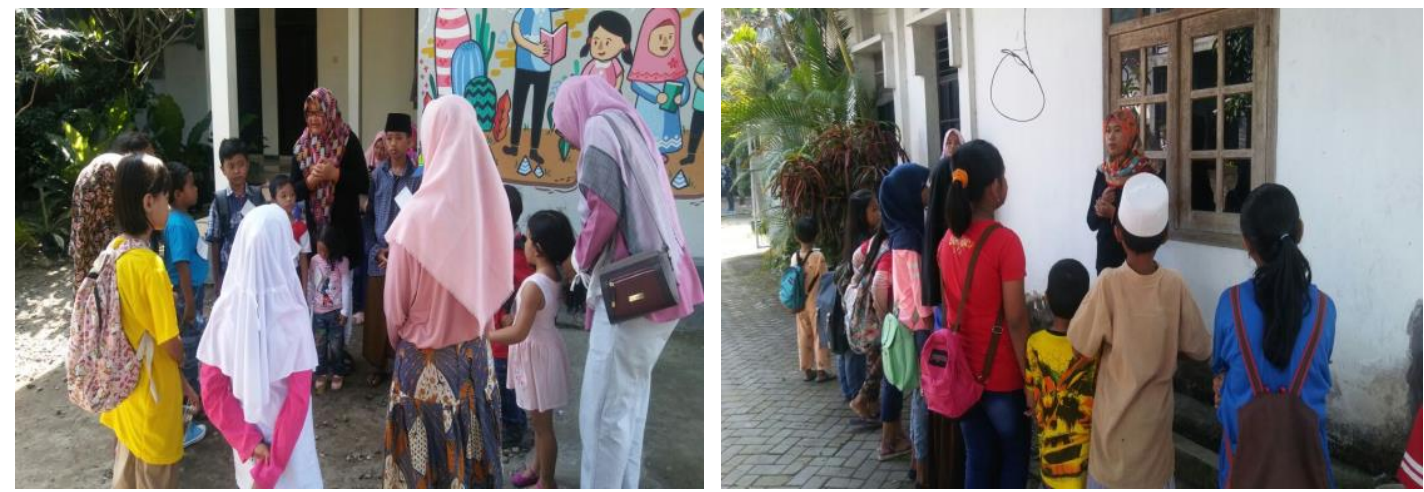

Gambar 3. Kegiatan jelajah kebun. Pos 1 (kiri) dan Pos 2 (kanan)

Sedangkan pada kegiatan jelajah kebun, anak-anak diajak untuk saling mengenal anggota kelompok serta mengenali lingkungan sekitar mereka. Pada pos 1, anak-anak didorong membangun rasa percaya diri untuk menunjukkan dirinya dan berinteraksi dengan teman-teman baru. Menyebutkan nama lengkap, nama panggilan, usia, sekolah di mana, serta kelas berapa. Pada proses ini, anak akan memahani dan mempraktikkan bagaimana berbagi dan menerima informasi secara setara dengan teman sepermainan. Di sini dipupuk rasa toleransi dan membangun kepercayaan dalam kelompok.

Pada pos 2, anak-anak berinteraksi dengan alam. Mereka diajak untuk mengamati lingkungan sekitar dengan mengindentifikasi nama-nama benda dengan bahasa Inggris, juga sifat dan kegunaannya. Pendamping kelompok menunjuk batang pohon, daun, bunga, buah, tanah, batu, hewan-hewan kecil, dan benda sekitar pos, lalu meminta anak-anak menyebutkannya dalam bahasa Inggris. Melalui proses identifikasi ini, anak-anak diharapkan memiliki kepekaan terhadap lingkungan serta lebih menghargainya dengan merawat dan melestarikan alam.
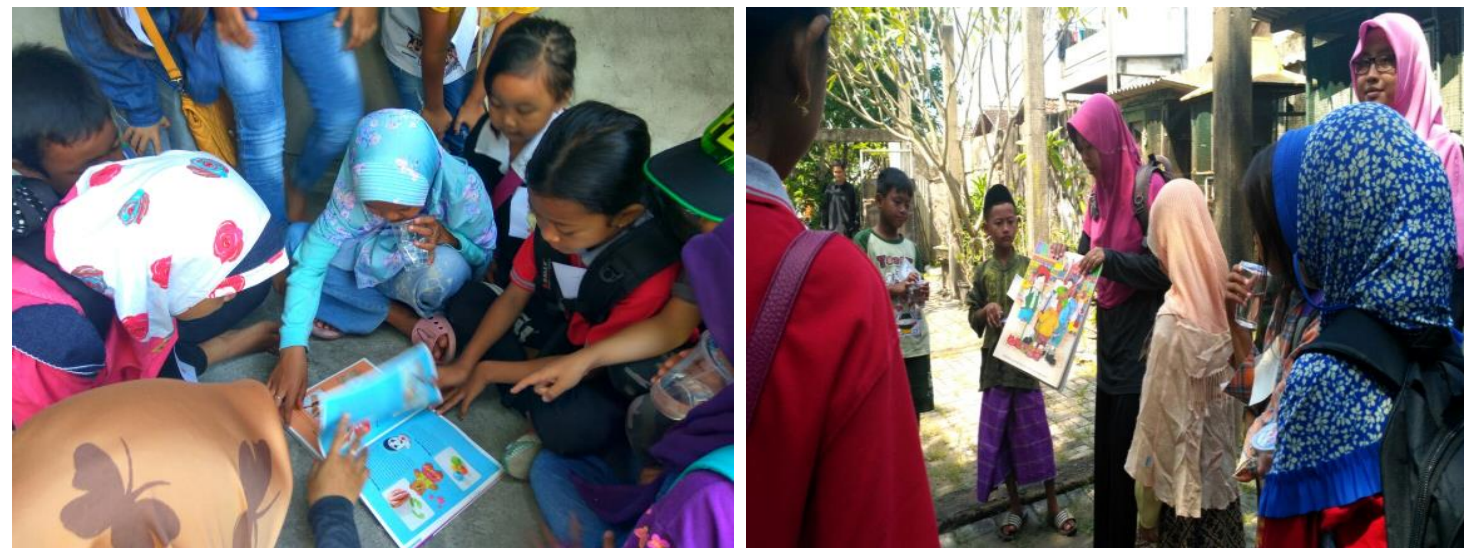

Gambar 4. Kegitan jelajah kebun Pos 3 (kiri) dan Pos 4 (kanan)

Di pos 3, anak-anak diberi kebebasan untuk membaca buku cerita berbahasa inggris yang telah disipakan oleh panitia. Antara lain buku cerita berukuran besar dan berwarna-warni berjudul Pinnochio, Hansel and Gretel, Illama Illama Misses Mama, dan My Cookies. Kegiatan membaca ini memupuk kecintaan anak-anak terhadap buku serta membangun koherensi berpikir antara isi 
dalam buku dengan lingkungan sekitar mereka. Tahap ini berupaya membangun imajinasi anakanak atas apa yang mereka baca. Imajinasi merupakan hal penting yang harus dimiliki pembelajar dalam proses visualisasi materi di dalam otak anak. Melalui imajinasi tersebut, anak-anak akan terangsang untuk membangun pemahaman secara utuh terhadap suatu konsep atau isi dalam buku.

Di pos 4, anak-anak diajarkan untuk mampu menceritakan kembali apa yang telah mereka baca di pos sebelumnya. Proses review ini merupakan upaya untuk mengintegrasikan pengetahuan dan rasa percaya diri anak untuk menyampaikan pendapat. Argumentasi yang mereka bangun merupakan suatu hasil belajar yang mereka susun secara bebas, sesuai dengan cara belajar mereka masing-masing.

Tahapan belajar yang dilakukan anak-anak pada kegiatan di atas merupakan praktik dari proses pembelajaran kritis dengan acuan consciaentizacao. Anak-anak memiliki kebebasan dalam berekpresi dan memiliki cara belajar mereka sendiri. Panitia hanya berperan sebagai fasilitator untuk memantik kemampuan belajar anak. Pada dasarnya setiap anak memiliki metode belajar sendiri, sesuai dengan kesukaan dan kemampuannya. Maka, yang perlu dilakukan adalah anakanak diberi kesempatan untuk mengekspresikan dirinya. Ini yang disebut Freire sebagai praxis, yaitu kondisi manusia yang terilhami untuk menunjukkan adanya kesatuan fungsi berpikir, berbicara, dan berbuat [4]. Untuk membangun sistem belajar tersebut, sering kali perlu adanya penolakan atas sistem pendidikan "gaya bank" yakni anak-anak dihadapkan pada sistem pengobyekan anak didik, dan menganggapnya sebagai benjana kososng yang siap dijadikan obyek investasi dan sumber deposito potensial.

Sebagai individu yang bebas, anak-anak menjadi bagian independen dalam proses penciptaan wajah penididkan di Indonesia. Anak yang belajar dengan kebebasan dan kebahagiaan akan menghasilkan generasi yang cemerlang, karena mereka terbebas dari pengekanganpengekangan yang membuat kreatifitas mereka terhambat. Pada kegiatan ini anak-anak sangat antusias, yang ditengarahi oleh respon anak-anak yang disampaikan secara langsung pada akhir kegitan dan beberapa menuliskannya pada lembar refleksi.

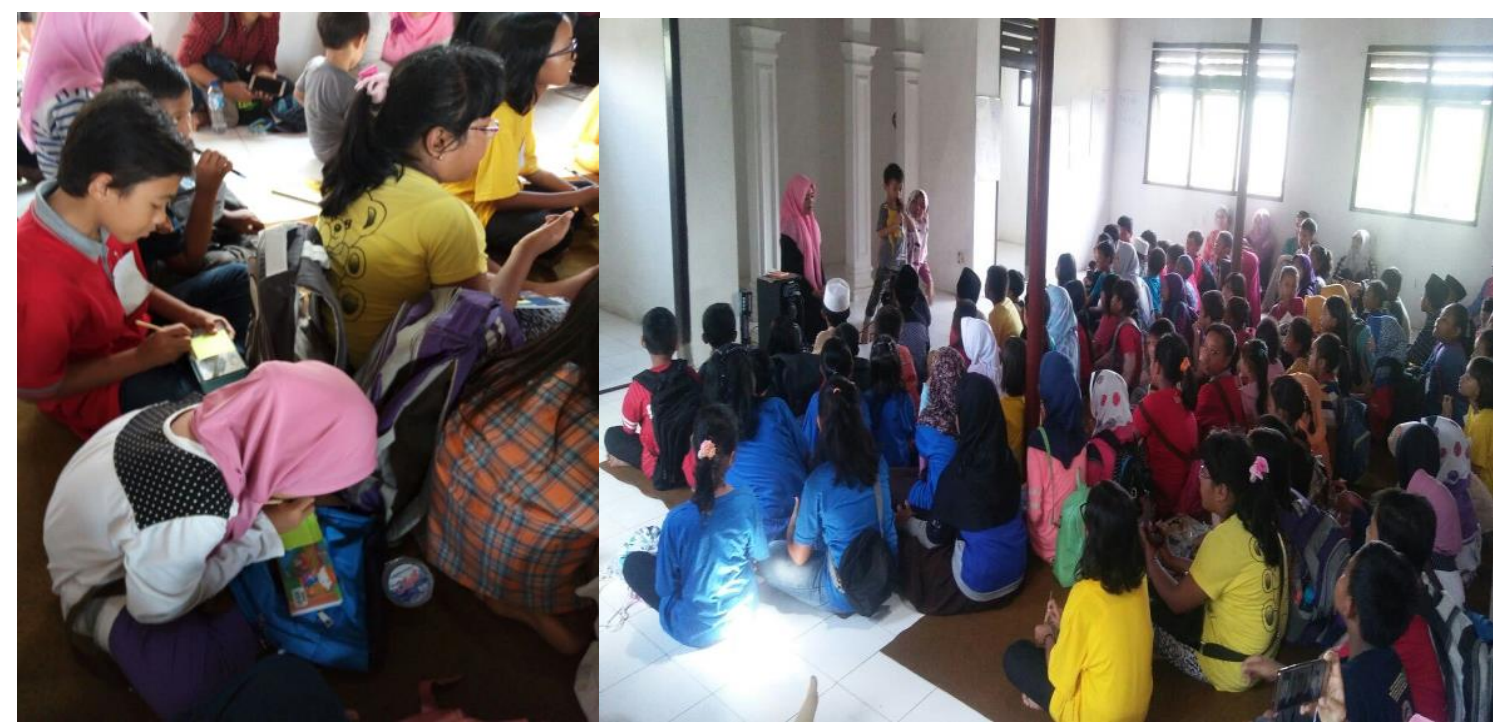

Gambar 5. Refleksi kegiatan disampaikan langsung (atas) dan dituliskan dalam lembar refleksi (kiri) dilakukan oleh anak-anak di akhir kegiatan

Anak-anak bercerita bahwa mereka merasa senang dapat berkomunikasi secara langsung dengan American Natives, sebagai pengalama baru bagi mereka. mereka juga menuliskan bahwa belajar Bahasa Inggris itu mudah, dan menanyakan kapan akan ada lagi kegitan serupa di Taman Baca Puri Anjali. Refleksi singkat dari anak-anak ini memberikan gambaran bahwa kegiatan belajar dengan metode bermain ini merupakan kegiatan belajar yang dibutuhkan anak-anak. Selain mereka mendapatkan pengalaman baru, mereka juga mendapatkan pengetahuan baru serta mereka merasa bahagia. Kebebasan belajar yang membawa banyak manfaat bagi anak-anak, yaitu secara kognisi, psikomotorik, maupun rekresasi. 


\section{KESIMPULAN}

Kegiatan berliterasi merupakan kegiatan keberaksaraan, tidak hanya terpaku pada buku. Kampanye literasi bisa dikemas dalam bentuk permainan seru, tanpa meninggalkan esensisnya untuk menyerap inti informasi dari buku. Demi menguatkan kemampuan berliterasi, khususnya anak-anak, penting dilakukan oleh pegiat literasi untuk mampu menangkap peluang-peluang baik untuk menularkan pengalam belajar pada anak-anak. Taman baca tidak lagi relevan jika hanya menjadi bangunan sepi dan kaku, sekedar sebagai tempat meminjam dan membaca buku. Bagai taman baca yang berfokus pada literasi anak, perlu dipahami bahwa pada dasarnya anak-anak senang bermain, kadang kesenangan ini lebih besar daripada kesenangan membaca buku. Maka perlu adanya tawaran alternatif kegiatan yang berbeda dari rutinitas anak-anak di sekolah. Inilah salah satu upaya untuk bertahan dari gempuran teknologi informasi yang sudah merasuki anakanak.

\section{SARAN}

Perlu adanya penguatan relawan di Taman Baca Puri Anjali dan penyusunan program kerja bulanan dan tahunan agar adanya kesinambungan aktivitas yang bisa ditunggu oleh anak-anak. Untuk kegiatan serupa perlu adanya relawan yang lebih banyak, sehingga semakin banyak pengalaman positif yang dapat dibagikan kepada anak-anak. Sudah selayaknya taman baca menjaga relasi baik dengan berbagai pihak untuk terus memberikan inovasi kegiatan belajar bagi anak-anak. Jariang yang luas akan memberikan kemudahan dalam mengakomodasi relawan taman baca lain yang potensial dan relevan untuk kegiatan-kegiatan menarik lainnya.

\section{UCAPAN TERIMA KASIH}

Atas terselenggaranya kegitan ini ucapan terima kasih disampaikan kepada:

1. Relawan Taman Baca Puri Anjali, Kaliombo Kediri.

2. Relawan Gerakan Perpustakaan Anak Nusantara (GPAN) Kediri

3. Tutor English Massive di Kelurahan Kaliombo, Dukuh Corekan, dan Kelurahan Kampung Dalem, Kediri

4. Para orangtua yang telah mengizinkan anak-anaknya mengikuti acara ini.

\section{DAFTAR PUSTAKA}

[1] Imron, Ali, (eds), 2016, Khasanah Sosiologi Pendidikan, Unesa University Press, Surabaya, hal. 160.

[2] Liliweri, Alo, 2009, Makna Budaya dalam Komunikasi Antarbudaya, LKiS, Yogyakarta, hal. 71-72.

[3] Smith, William A., 2008. Conscientizacao: Tujuan Pendidikan Paulo Freire, Pustaka Pelajar, Yogyakarta, hal. 4.

[4] Rahardjo, Toto, et, al., (eds), 2010, Pendidikan Popular: Membangun Kesadran Kritis, InsistPress, Yogyakarta, hal. 60. 